\author{
Iwona Lorenc \\ https://orcid.org/0000-0003-3364-3953 \\ Institute of Philosophy \\ University of Warsaw
}

\title{
DISCURSIVENESS OF ART AS A PHILOSOPHICAL PROBLEM
}

\begin{abstract}
Is it still possible to speak of an opposition of linguistic discourse and art after the notions of language, as well as discourse and the discursive have undergone a significant reformulation and expansion? To answer this question, I distinguish between the notions of discourse and the discursive. I transpose this distinction onto the level of reflection on art as one of signifying practices. I show how the deconstruction of Western discourses on art is accompanied by the recognition of discursiveness of art by Heidegger, Derrida and Marin; like Merleau-Pointy, I search for the conditions of significant production underneath or "before" historically established discourses, expanding the idea of discursiveness of art in the sense that I adopt. I connect Lyotard's concept of visuality with the understanding of discursiveness of art that I propose: as a field of productivity of meanings, a primary impulse of discourse; the thing that enables speaking and imaging, without which speech and image are impossible.
\end{abstract}

Keywords: discourse of art, discursiveness of art, language, literature, painting, the visible, the invisible, visuality

\section{Initial assumptions}

Nietzsche sees a connection between the horizon of language and the horizon of metaphysical questions, saying that our "faith in grammar" is a kind of theology, and our thinking always happens within the confines of the prison of language. This prompts us to revisit the question of the illusions held by some philosophers who believe that it is possible to examine the "truth of art" prior to, underneath, independently from or even against language, in opposition 
to what can be expressed in language and captured in discourse. After all, the truth of art is supposed to be - as Habermas would have it in The Philosophical Discourse of Modernity - "a Dionysian gate" that allows philosophers to escape the metaphysical stronghold towards the mythologized originary that is untainted by language and escapes discourse. Is it still possible, however after Heidegger and contemporary hermeneutics, Foucault, Derrida, certain varieties of post-phenomenology, Lacan or the post-humanist version of new materialism (Haraway, Barad) - to speak of an opposition of linguistic discourse and art? After all, the notions of language as well as discourse and the discursive have undergone a significant reformulation and expansion. This process took place not without deep philosophical reflection on art and impulses coming from artistic practices that put the very opposition into question and blur it.

I distinguish, similarly to one of important contemporary theorists of discourse, David Howarth ${ }^{1}$, the notions of discourse and the discursive. I transpose this distinction onto the level of reflection on art as one of signifying practices. In this view, discourse - historically shaped and consolidated systems of meaning (e.g. discourse on art that functions in the Western culture of mimetic representation) - is distinct from the discursive, understood "as a horizon of meaningful practices and significant differences"2 (e.g. discursiveness of art as a signifying practice which gains independence from other practices, as well as its inherent ability to create meaning thanks to a special (aesthetic) connection between the meaningful and the material, sensual, affective). In this broad sense, the discursive is not synonymous with a reduction to the linguistic, understood as a codified system that delimits and orders the field of what can be expressed with words, and then fixed in writing. Heidegger, Gadamer and other philosophers that will be discussed here broaden and modify the very concept of language as well. People "thrown into the world" - to put it in Heideggerian terms - experience objects, other people and even their own selves as phenomena imbued with meaning, and the world - as an environment that is permeated by the discursive and the linguistic. The discursive understood in such way means a set of conditions that enable not only understanding, interactions and communication between subjects, but our very encounters with the objects of this world on the whole.

Meanwhile, critical discourses of philosophy - in the spirit of the already mentioned Nietzschean rebellion against the bondage of language - wage a battle against language and discourse for the originary and the authentic, looking for allies in the realms of art as well as artistic and aesthetic discourses of mo-

Cf. D. Howarth, Discourse, Open University Press, Buckingham UK, 2000.

Ibid., p. 9 
dernity. In the works of Heidegger, Marin, Derrida and Lyotard, these themes intertwine with criticism of philosophy of representation.

\section{Deconstruction of Western discourses on art versus recognition of the discursiveness of art: Heidegger, Marin}

Heidegger's position on the above matter is somewhat ambivalent: in his critique of representation of Western culture, the longing for the originary of the pre-discursive and the pre-linguistic is accompanied by an attempt to reformulate both categories and give them new meanings. On the one hand, in Heidegger we find the echoes of nostalgia for the sensual, nearness of the thingin-itself, untainted by representation, a nostalgic and utopian motif of treating aesthetic experience as a means to reach the originary (that can also be found in Merleau-Ponty or Dufrenne) and this aspect is highlighted in the critique of Habermas mentioned earlier.

On the other hand, however, Heidegger's analysis of aesthetic experience is not so much about the sphere of sensuality or emotionality - "pure" and free of representational (conceptual or pictorial) treatment, but rather about the logos of the work of art, where the sensual becomes a dialectical moment of specific interplay of concealment and unconcealment. According to Heidegger, the idea of originary explanation of phenomena should be put into practice as a concrete hermeneutic task facing the human being in the world. This task consists in bringing out what is concealed in connection with its unconcealment. Here, phenomenological themes take on the character of hermeneutic postulates, which is especially evident in Heidegger's late work. As we are placed in logos and condemned to commune with representations, where the fundamental experience of Being is speech, we face the world as a world that obscures representations. At the same time, that very speech - as a fundamental experience of Being - grants us access to its openness through "poeticizing" art. Being manifests itself in poetry.

The receptive experience of sense given in poetry, acceptance of the happening of Truth is one of the ways to release language from the confines of metaphysics. This means a kind of continuation of Husserl's genealogical path: reaching the "essential framework of speech" as something "prior" to the already shaped structure of meanings of language; it also entails the necessity to deconstruct established meanings. This path, which can be traced back as far as Ideas and Logical Investigations, leads in an entirely different direction than Husserl's idealistic commentaries, namely - towards hermeneutics.

The first significant attitude towards things, which is the source of interpretative distance, appears already at the level of perceptual experiences. In the womb of these experiences - as Heidegger points out - speech (Sprachlichkeit) 
is born; that is a linguistic order that culminates on the plane of logical meanings of language. "It is this referencing of the linguistic order to the structure of experience (which reaches language in utterance) that creates (...) the most important phenomenological assumption of hermeneutics”, says Ricoeur ${ }^{3}$.

According to Heidegger, the course of European metaphysics that was set out by Plato is a journey from indicating to signifying, from logos to language, towards a displacement between sense and meaning. It is the philosopher and the poet - in mutual support - who are most sensitive to the displacement, as they are predestined to use the domain of this difference as the element of their own language, in order to reanimate, in a hermeneutic effort of understanding, its function that has been pushed to the margins by metaphysicians and linguists - the function of evoking presence.

What presence are we talking about though? To answer this question, I will once again refer to Ricoeur. As the French philosopher notes, Husserlian ontological explication, which is Auslegung at the same time, "consists in the spreading out of the layers of sense (nature, animality, psychology, culture, personality), which constitute the world as a constituted sense in a layered manner"4. The experience of the presence of the world afforded by language is not a raw experience of something given prior to my understanding participation in the world. It is as much a phenomenological as a hermeneutic experience.

This positions clears the pathway for the philosophers who, although they do not draw directly on Heidegger, similarly to him critique traditional concepts of representation and traditional approaches to art.

In his book De la representation, Louis Marin, whose intentions, at least in this respect, coincide with Heidegger's, demonstrates that the question of the "depth" of painting, i.e. of its discursive narrative content, its anecdotal descriptive meaning, exists only in connection with questions about its "surface", i.e. its "empirical body" that yields to symptomal analysis. The questions taken all together make up an analysis not of the visible and not of vision itself - treated separately - but instead an analysis of a problem field which he calls the field of vision.

In this perspective, Marin finds commonalities with a reworked phenomenological and Heideggerian tradition as well as Damisch (namely with the analysis of visibility as a mechanism that constitutes the space of symbolic culture). Similarly to Merleau-Ponty or Lyotard, he links together the questions of speech and silence of painting. In his view, the phenomenon of painting maintains a relationship with language and the discursive in the sense I have men-

3 P. Ricoeur, Struktura a znaczenie w mowie, in: Egzystencja i hermeneutyka. Rozprawy o metodzie, trans. J. Skoczylas, Warszawa, 1985, p. 218.

4 Ibid., p. 230 
tioned in the introduction. Against the dominating tradition of the West that subordinates painterly means of expression to linguistic sense, painting would escape the dictate of discourse characteristic of Western representation.

Marin's critique of Western mimetic discourse is about artificial dichotomies between the discursive and pictorial side of painting. An image built according to the rules of mimesis allows us to see the represented thing, realizing the idea of cognition as vision, a metaphor of the "inner eye" of consciousness. If the signs of language stand in for concepts, then pictorial signs stand in for things. The rules of this substitution are guarded by cultural convention which requires the painted image to be immediately named. Image is therefore a kind of a reproduction, in line with the rules of the visible, the structure that generates language in its intelligible order. Both language and image are affected by the same atrophy of materiality: in the domain of language, the domination of intelligible sense leads to the effacing of the material aspect of the linguistic sign, i.e. sound. In painterly reproduction, which is accompanied by the normative requirement of "legibility", what is effaced is, for instance, the materiality of foundation or colour pigment in favour of what can be seen, recognized and named. European culture aisthesis of representation has been dominated by semiology, by the sign, and subjugated to the function of communication.

According to Marin, the essence of the operation of transforming the world endowed with meaning into discourse is duplication, the replacement of the presence of sense by the word. The word is a derivative presence which, by revealing its fictionality, reveals to us the absence of the world to which it refers. The word, or more broadly, the symbolic order of culture is constituted by difference, the relation with what is other and what is the "obscured second half of the meaningful word". The thing does not present itself "in its own self", as given directly in its own being, but through what is other or in relation to the other. The word is filling a lack. Therefore, the prerequisite of discourse is the absence of the thing, its deficit or shortage. This "nothing" is an empty space in the tissue of phenomenal experience of the world. What breaks into it is discourse, "...a new reality as communication, as the being of communication itself" 5 . The topography of phenomenal experience is transformed into a narrative topics of communication. In a certain metaphorical sense, speech takes the empty space left after being.

One can see here a coincidence of influences in Marin: Benveniste's linguistic critique and late Heidegger's battle to wrest speech as an event from the plane of unifying logos. There is also an affinity in the tendencies of both philosophers to interpret language as dialogue, against the monological onto-

5 L. Marin, De la représentaion, Gallimard, Le Seuil, Paris 1994, p. 132. 
theocentrism of the signified which characterises European tradition. Lyotard, as we are going to discuss later, followed the same lead.

\section{Discursiveness of art as a game for truth; a literary strategy of deferring the truth}

Thanks to Marin, we reach a place in which it is necessary to have a closer look at the essential distinctions between the two initially introduced optics, two ways of analysing the question of discursiveness of art: the first one - critical towards universal linguistic discourse (as significant representation) and the second - related to the discursive in its broad sense, where art as an event is a space of constantly sustained interplay of meaning and sense, indication and signification. The second approach entails leaving behind the illusion of the possibility of reaching the ultimate truth through art, however such truth is understood by philosophers.

In this respect, literature - the art of language - fulfils a truly paradoxical task, because by the power of language it utilises, it is condemned to promising and at the same time deferring access to the truth of the "represented thing". This dilemma is brought to attention by Derrida on the plane of philosophy.

In the spirit of Nietzschean-Heideggerian critique, Derrida questions the very posing of the problem of relation between thought and word. He undermines the ultimate primacy of the signified in relation to the signifier as a sign of metaphysics of presence, characteristic of Western philosophy, and consequently the illusion of the existence of final knowledge that would give access to the pure presence of sense. Faith in this presence, accessible by way of ideal cognition, marks a horizon (barrier or fencing - clôture) of Western philosophy. The limits of its powers are built using language in the form of hypostases of the idea of complete presence (of the thing-in-itself, God, substance, the content of pure consciousness, etc.).

If we are, as Nietzsche sees it, prisoners of language condemned to metaphysically laden concepts, we can only make sure to inflate the concepts in such a way as to not destroy them (as it was suggestively said by Levinas who agreed on this point with the premises of Heidegger's and Derrida's strategies). Derrida, similarly to Heidegger, follows the lead of etymological argumentation, performing a kind of an assault on language that has the tendency to sediment meanings. This strategy does not allow language to "settle down", get fixed in the illusory substantive and substantial order. The strategy has a multitude of uses in contemporary philosophy of art. For example, Barthesian Lover's Discourse: Fragments deconstruct narrative structures of discourse; as an example of contemporary fragmentaristics, they are an instance of late modern work of the said deconstruction, next to such philosophers as Adorno (with his 
micro-narrations), Benjamin (with dialectical image) or Lyotard with his pagan "satirical politics".

Lyotard claims that truth - understood as Aletheia, and not Veritas - is a happening, it comes absolutely unexpectedly and cannot be confined to a priori rules of discursive knowledge; it is neither presence, nor a search for any presumed hidden presence. In his view, there exists such a possibility of interpretation of discourse where it could be openness to what is happening. Such an interpretation cannot treat the interplay of what is external and what is internal to discourse in terms of dialectics because such an interpretation, as he notes in his critique of Hegel, absorbs and levels out all exteriority. Truth is not a property of discursive knowledge, it is rather something shocking and unexpected from the perspective of this order. Like Freud, Lyotard notes that it is an aberration, a distortion of the established order of meanings. Hence, the task of the philosopher is to shock within the confines of discourse, to deconstruct its order.

In Roland Barthes' opinion, it is also the task of literature. Barthesian Lover's Discourse: Fragments demonstrate the antinomy of literary discourse, comparing the experience of literature to the experience of love, where affirmation is accompanied by a negation of the object. In literature, what is affirmed and negated at the same time is language. Barthes is interested in the liminal point of contact between discourse and the unfathomable energies from which the linguistic discourse emerges and which resist it - the energies of desire/drive and imagination. There is a curious affinity between the figurality of Barthes' Lover's Discourse: Fragments and Lyotard's Discourse, Figure. No direct references can be found between them - both books express the spirit of their times in parallel rather than prompt us to deliberate about the relations of priority or influence. In both cases, however, the figures of discourse are atopos (they do not belong to a set place), idiomatic (freed from the reigns of grammar, they are one time happenings) and non-hierarchical - "horizontal", as Barthes says. The figures are neither connected by any logic, nor determined by their adjacency: they remain outside the syntagm, outside the story.

Literary space of created significances interweaved with other texts and codes is a moving space; it is in the process of generation, constantly open to new meanings. Barthes decidedly steps beyond structuralism, denying the possibility of capturing text in a network of structural interconnections. The structure is not finished, he says, there is no one centre that can be located, nor are there any established rules for its construction. Sense is not something pre-existing, waiting to be expressed, but rather a happening of symbolic space of culture that generates the subject. The subject, traditionally understood as the author or the reader, is only a place where the senses meet, a place that is impossible to locate because they are labile fields of permeating codes that constitute themselves for the use of the game - i.e. reading. 
This method in its principle stands against any form of hierarchization, especially against the ontotheological situation of the signified in the position prior to the signifier as well as against metaphysical hypostasizing of the subject and its consciousness as a residuum of significant sense. Literature is understood as a happening of speech itself. It is not a reproduction or a presentation of pre-existing sense waiting to be expressed, neither in the solitary life of consciousness, nor a "state of things" constituted by nature or society. Barthes's take on literature is anti-mimetic.

In his approach, the functioning of the symbolic culture of modernity is based on a model of exchange. Narrative culture is interested in deferring access to truth by complicating the structure of naming in the process of unending equivocation of the signifier and the signified. Truth as a name is a task but at the same time an impossibility for thus understood, "liberated" language of modernity: "the truth is thereby long desired and avoided, kept in a kind of pregnancy for its full term, a pregnancy whose end, both liberating and catastrophic, will bring about the utter end of the discourse; and the character the very arena of these signifieds is only the enigma's passage, the passage for this nominative form of the enigma with which Oedipus (in his debate with the Sphynx) mythically impregnated all Western discourse." ${ }^{6}$ The paradox is that (like in Blanchot where death is inscribed in literature) for Barthes the success of naming would mean death.

Discourse, whose personification Barthes sees as a historical and cultural fact, is "interested" in deferring access to truth to the highest degree: "To narrate (in the classic fashion) is to raise the question as if it were a subject which one delays predicating; and when the predicate (truth) arrives, the sentence, the narrative, are over, the world is adjectivized"' . Discourse (literary narration) is therefore an answer to the metaphysical need for truth and its discovery. One of its mechanisms, however, is that it meticulously conceals its own "agency" in generating mechanisms of revealing/deferring the truth, creating illusions of subjects (the author, the reader) or illusions of originary sense, in the creation of their respective discourses.

Discursiveness of literature - the strategy of difference and "deferring" highlighted by Derrida or Barthes - is thus a field of productivity that creates meaning, which performs its work by deconstructing the existing discourses while at the same time producing them. The mechanism is discovered - in a different way and in relation to a different art medium, namely painting - by philosophers such as Merleau-Ponty or Lyotard.

\footnotetext{
R. Barthes, S/Z, trans. Richard Miller, Blackwell, New York, 1990, pp. 62-63. Ibid., p. 76.
} 


\section{The silent speech of painting as the discursive versus discourse: Merleau- -Ponty, Lyotard ${ }^{8}$}

Louis Marin aptly notes that the visibility of painting is possible only on condition of the spectator's engagement, i.e. on condition of annihilation of the "screen", dispelling of the myth of impartial, disinterested, contemplating consciousness - an idea preserved throughout the history of aesthetics and fuelled by the Platonic model of bios theoretikos. The interplay of sense and meaning in painting, of indicating and signifying, creates a tension that is able to put resistance against mimetic interpretations of representation. By virtue of this tension, a painting - irreducible to discursive description - is characterised by a certain surplus of sense in relation to significant interpretations.

In Ricoeur's "Structure and meaning in speech", we read: "When Husserl states that all consciousness is consciousness of something, that all consciousness is intentional consciousness, he tries to position the sign with its dynamics much lower than speech (...). All philosophy that has emerged from phenomenology, in particular that of Merleau-Ponty, is devoted to that power of signifying something, which is prior to speech and in which speech resides. Merleau-Ponty shows us that in the most elementary perception, the relations that take place between the senses, between senses and motor skills, between qualities, between objects, etc., constitute a kind of significant tissue that enables speech. We speak because in our elementary life there is something like a primal power of signifying something, on which speech will be articulated." ${ }^{10}$ As we know, the task of hermeneutics according to Ricoeur differs from Husserl's as well as Merleau-Ponty's. What ties both these philosophers, however, and what allowed Ricoeur to make the above statement, is the conviction that speech is only a special case of articulation of something more fundamental to it.

For Merleau-Ponty, aesthetic experience allows us to return to bodily perception of the world, where mediation through conceptual discourse is unnecessary. At the same time, paradoxically, it is not the conceptual discourse but aesthetic experience that is "closer" to the essence of language itself. What is meant here is language yet unspoken, "language of silence". To reach it, one has to break through the distorting barriers of the language of concepts. It is a difficult task for a philosopher, as it requires - as we read in The Visible and the Invisible - "... speaking (...) not according to the law of the word-meanings inherent in the given language, but with a perhaps difficult effort that uses the

8 Merleau-Ponty's and Lyotard's concepts are discussed in my Polish book Świadomość i obraz. Studia z filozofii przedstawienia, Warszawa 2001.

9 P. Ricoeur, Ibid., pp. 285-286.

10 Ibid. 
significations of words to express, beyond themselves, our mute contact with the things, when they are not things said" 11.

One way to capture this originary relationship to the world is thus not to reject reflection but to transgress the limits of its possibility, in particular the limits of the language of concepts, which - like a screen - obscures things. What is meant here is of course not a resignation from linguistic forms of expression, but a new way of treating language. The "thing" to which the language refers us are not linguistic meanings, as semantic theories would have it, but it is a way in which the things themselves "speak", spaces of opening, a way in which the world offers itself to us perceptually.

In fulfilling this task, the philosopher is aided by the artist. If, in line with Husserl's intentions, Merleau-Ponty's philosophy is moving towards a restitution of the possibility of meaning, birth of sense, then aesthetic experience is especially well-equipped for this task. Similarly to perception, it consists in neither reception of ready meanings, nor contact with things that are waiting to be bestowed with meaning. The world evoked in aesthetic experience is only seemingly a world present in itself. What stands before us by virtue of this experience is not a world in all of its raw facticity. A line, a colour, a word refer us to something even more prior than the thing, to something which makes the thing present at all and the world endowed with meaning.

Colour, for instance, is not an imitation of natural colour. Lines of drawings in Lascaux are not visible for their own sake; they arrange a certain ordering of space in the field of visibility of the world, their function is diacritical. In the experience of painting, one does not see a line, because it evokes what is invisible: it opens up a dimension of the hidden invisible spatiality of the thing and the world. What constitutes sense is outside the work of art, in a "surplus" which the eye cannot see and which it serves both as a witness and a guardian.

Merleau-Ponty (especially in his late works) sees such areas as language as well as artistic, philosophical and scientific articulations as varieties of amplifications of the primal sensual experience which reveals the presence of the world in the dialectics of the visible and the invisible. The main protagonist of this "drama" of visibility and invisibility is not the perceiving subject, nor the perceiving and perceived body, but being. It is being that "makes itself visible" in the Heideggerian-like interplay of concealment and unconcealement.

The visible (in the sense of the evident, what can appear) is the principle of being, its element. In perceiving the world, in art, in philosophy and even

11 M. Merleau-Ponty, The Visible and the Invisible: Followed by Working Notes. Northwestern University Press, 1968, p. 38. 
in science, we participate in the process of being becoming visible. It becomes visible in us, in our experience. It is not us, however, who constitute the sense of the world in the conscious activity of subjects endowed with will ${ }^{12}$. The sense is hidden in the interplay of the visible and the invisible, and human activity word and thought - are only moments in this movement; sense is irreducible to them. Philosophy, science and art are ways in which "being speaks", ways in which the mystery of its sense is in the process of being endlessly established, and the discovering of this mystery is never finished.

Image, similarly to signs and speech, says the French philosopher, does not refer to existing things. It is merely a hint, a means of the formation of an idea of the thing, "a text" that is proposed to us for reading and not a misleading delusion placed between us and things. Image is not a kind of double participation of things in the world, art is not an oneiric world of analogies of reality. And the "thinking of vision", as an experience of sense given in vision ( $\log o s$ inherent to vision), is not a form of the subject's activity, but rather its receptiveness, opening to the world and, in the French philosopher's words, "a mystery of passivity". That is because the fundamental characteristic of seeing is its intentional character; it always points to the thing itself, not its transcendence. It is an experience of expressivity inherent to things, their being visible.

For both Husserl and Merleau-Ponty, sense is something prior to conceptual logos. Merleau-Ponty claims that there is a "logos" of the prediscursive, he seeks for conditions of significant productivity underneath or "prior to" historically established discourses and therefore expands the concept of discursiveness of art in the sense I adopted; it is "a system of equivalences, Logos of lines, lights, colors, masses, the conceptless presentation of universal Being" 13 .

The revolution of vision that came about thanks to contemporary painting consists in releasing seeing and its logos from the confines of conceptual thinking. The subject of contemporary painting became the "order" of appearance of things themselves that is inherent in the experience of seeing, the system of equivalences hidden under the schemas imposed on metaphysical vision, this conceptless presence of the universal Being.

One example is the treatment of line and outline to which contemporary painting has a different approach. The boundaries of things do not belong to the things themselves, as traditional painting would have it. And this is not me-

12 In this respect, I do not see in late Merleau-Ponty a return to traditional metaphysics, but rather an opening of philosophical reflection to transhumanist aspects of processes of constitution of sense and material signifying practices. It is interesting to read these themes through the propositions of Donna Haraway or Karen Barad (who, in fact, refers directly to Merleau-Ponty).

Ibid., p. xlv 
rely about doing away with the line as it was done in impressionism, but rather about freeing the line and reinstating it with constitutive power, as is the case with Klee or Matisse. According to Klee, the line does not imitate the visible but makes things visible, it is the "outline of genesis of things", it has diacritical meaning as a foundational axis of human seeing of the world. As in the case of Leonardo da Vinci, we can speak here of a kind of "pictorial knowledge" which reveals the mysteries of the universe through the experience of sensual objects (which paintings after all are).

For Merleau-Ponty, "aesthetic logos" precede the order of discursive cognition. A work of art in contrast to the system of language is not a tool of universal communication. In a conversation, scientific or philosophical discourse, the sounds of speech are subordinated to the central task of communicating sense, and so they might be ignored in favour of sense. Meanwhile, the idea of music with no sound is absurd. Art, irrevocably tied to sensual means of expression, as aesthesis, might be interpreted as a closed universe that does not refer itself to the transcendence of meanings which the intentions of speech acts are directed to. "Logos" to which art refers is - as I have noted before - the sphere of primary ordering, prior to the emergence of the division into the word and the thing, where sense is yet inextricable from its manifestation, from its sensual and material dimension.

This silent sensual order that precedes linguistic articulations it not, however, entirely independent, exactly because of its antecedent nature. In The Visible and the Invisible, we read: "Yet there is a world of silence, the perceived world, at least, is an order where there are non-language significations - yes, non-language significations, but they are not accordingly positive"14. Silence of the perceived world and especially the silence of a painting, its hidden order, is a set of possibilities realized by language.

The task, therefore, is to give an account of this silent life of concepts before they were born. It is not about rejecting discourse but placing it in a different space, in which they could become a culmination of the originary mystery of our sensual contact with the world and its inherent sense, an ordering nascent in its field.

It is not us who speak using language, but it is being that speaks in us through language, while the aesthetic experience that descends to places from which language emerges is a form of reintegration of being, of its originary pre-conceptual order that was torn by Western culture. Phillipe ${ }^{15}$ claims that this task of philosophy's descent to pre-conceptual origins in Merleau-Ponty is

14 Ibid., p. 171.

15 M. D. Phillipe, Une philosophie de l’ętre est-elle encore possible? Edition P. Pégui, Saint-Genére 1975. 
accompanied by a sense of philosophical mission, because it is in the field of philosophy where the aging of intellect is most visible. Therefore, it should take upon itself the task of its "rejuvenation", realizing the idea of "transcendental openness of spirit" and descending to what is pre-conceptual.

Completing this task is possible, according to Merleau-Ponty, if philosophy itself is treated in terms of experience of being, if we affirm that it is being speaking through us. Phillipe believes that such a model of philosophy is an expression of nostalgia after divine, non-conceptual wisdom of love and silence, seeing it in the qualities characteristic of theological thinking. This line of critique is similar to Lyotard's critical reception of Merleau-Ponty who upholds his intention of freeing the invisible from the trap of conceptual discourse but wants to avoid the metanarrative and theological implications of the conception of the author of The Visible and the Invisible.

Lyotard sees the failure of Merleau-Ponty's project. He accuses him of "monotheism", as there is no interchangeability of the speaker and the spoken in Merleau-Ponty: what speaks is being. Meanwhile, as Lyotard stipulates in La philosophie et la peinture á l'ère de leur expérimentation (1985), no one knows what language is used by being, nor in what language it can be spoken of. No one even knows if we are talking about a single being or a single language of being. That is because philosophy is neither moving towards the unity of sense or being, nor transparency, but towards multiplicity and incommensurability of works.

In a way, it is a valid allegation against the author of The Visible and the Invisible as, for late Merleau-Ponty, what speaks in art and through art is being. Art has its own "logos" and its own eidetics. Even silence is another kind of "being speaking" because for Merleau-Ponty, who oscillates between phenomenology and metaphysics, there is no nonsense that would not fall under a variation of sense.

As for the question of discursiveness of art, the two philosophers have a lot in common, although Lyotard puts a lot of effort into maintaining and justifying the theoretical distance to Merleau-Ponty. First of all, what is important for the problems raised here, it is their tendency, which has common phenomenological roots, to broaden the category of sense to areas that fall outside of conceptual articulations (among which they attach great importance to the visible), searching for what is a mute articulation of sense before or in discourse.

The importance Lyotard attaches to the category of silence is tied to a critical aspect of his philosophical project. The task of critical reflection, contrary to constructions erected by the modernist philosophy of the subject is, in his view, not so much to discover what is to be said in the representations of culture, but also what is silent in them. This task of philosophical criticism, which allows Lyotard to enter into a discussion with Nietzsche, Freud and Heidegger, consi- 
sts in exposing the violence of discourse against which one can defend themselves only by referring to what is beyond discourse and what I call the discursiveness of art. Lyotard evokes the existence of a silent sense that runs along the border between words and things in an area yet unnamed, but placed at the root of all discourse.

Thinking about the presence of what is silent in a representation where discourse is only the surface layer appeared already in Lyotard's early work. In $L a$ phénoménologie from 1954, he highlights the paradoxical nature of phenomenology which, while carrying out the task of reaching the origin, uses language against its own self. This paradox sets a "line of resistance" of Lyotard's philosophy against the reduction of sense to the domain of language of meanings. The French philosopher, defending himself against such a reduction, is trying not so much to leave the domain of language but to bring language closer to what is unnameable. He is trying to make audible the "voice of silence" and "discord" (le différend). Finding an idiom that would be able to express the "inaudible" is the task of Discourse, Figure. Both this task and the ideas for creating a new theoretical space presented in this text - from the polyphonic space of language games to Kantian critical apparatus or Diderotian inspirations for philosophical discourse of a new kind - comprise a certain totality of Lyotard's philosophical idea. An idea that is probably heterogeneous, entitling us to detach the motifs that are of interest to us from the body of this philosophy, but still carried out with a determinable consistency by the philosopher.

One can find here a concept of a reflection that precedes the realm of argumentation and is rooted in the realm of affectivity, prior to rational discourse. He defines this field in terms of receptivity and "childhood of thinking" which can be found in the receptivity of aesthetic judgment, the trans-subjectivity that is prior to the constitution of individual subjects.

The radicalization of phenomenology appears to be in some respects similar to what took place in the case of Merleau-Ponty. In Lyotard's work, it also consists in the intention to philosophically transcend the area delineated by linguistic meanings towards something that had so far, in the European tradition, seemed to be a heterogeneous field, radically different from language, namely towards what is visible. According to Lyotard, the visible is not radically different from the utterable. On the contrary, it is its familiar, a so far underestimated way of existence. The field of the emergence of visibility, drawn across the horizon of what is visible, is wider than what is actually given to seeing; rather, it is visuality. In Lyotard, visuality is discursiveness in the sense I propose: the primary impulse of discourse, its constitutive distance, that is, what enables speaking and imaging, without which it is impossible to speak and visualize.

In Discourse, Figure, Lyotard defends the eye and its position in the discourse against Western phonologocentrism. The visible is what is radically 
and insurmountably outside, what cannot be internalized into meaning. The symbol "gives itself to thought," says Ricoeur. For Lyotard, it is above all what "gives itself to seeing". In the function of a figure (shape, form, the visible), the transcendence of the symbol disturbs the linguistic space, because it is an externality that resists reduction to meaning.

Each discourse has its object which it has as its "signified". Merely, this simple fact means that the elusive "truth" of discourse is not only a question of what words "want to say" and what they mean by virtue of their assigned meanings in language. The "truth" of discourse (its sense) that cannot be petrified into ready-made formulas is much broader, it is the truth of expression which plays the role of a "discourse within discourse", it is the other in discourse, its non-sense (if sense is reduced to the meanings of language). It is - as I conclude in the spirit of the distinction I adopted - the discursive that makes discourse possible.

There is an alternative between discourse as communication (discourse of meaning) and discourse open to discursiveness as a field of its own conditions. This alternative, according to Lyotard, arises from the history of Western philosophy, where questions about truth were conflated with questions about its discursiveness. Following the footsteps of Nietzschean-Heideggerian critiques of metaphysics, Lyotard says that truth - understood as Aletheia and not Veritas - is an event, it comes unexpectedly and cannot be captured by a priori rules of discursive knowledge; it is neither a presence, nor a search for a hidden but presupposed presence underneath what is evident.

Truth is not a property of the order of discursive knowledge. On the contrary, from the perspective of this order, it is shocking and unexpected. As in Freud, Lyotard notes, it is an aberration, a distortion of the accepted order of meanings. Hence, the task of the philosopher: "To shock within the confines of discourse means to deconstruct its order"16. The shocking event of truth that deconstructs the order of discourse is a revelation of what is external to discourse, what happens beside or even against its linguistic meanings, resistance, opacity, inertia in the face of the space of these meanings. Discourse may be treated the way we treat certain kinds of things as "figure-forms". It is "on the side of" things also because it has something to say, it takes upon itself the transcendence of things. The things that the discourse speaks about are always (like in Husserl) outside of discourse which testifies to this transcendence and reduces it at the same time: "[It] is on the side of things which are utterable and which need to be expressed. There is no discourse without this opacity, tending to [their] destruction and restitution at the same time"17.

16 J. F. Lyotard, Discours, figure, Klincksieck, Paris, 1985, p. 16.

17 Ibid., p. 14. 
Mechanisms of violence lie at the root of language. It is inseparably tied to both the process of becoming a sign of an object and the process of becoming a thing in discourse. Both speech and silence can be considered in terms of violence. Their interplay on the stage of discourse (the alternation of the function of concealing and unconcealing) takes a dramatic turn. The side of the "silent force" is embodied by "the eye" - the visual and at the same time the unconscious in discourse, such as the opacity of meaning (sensuality, "thickness", materiality). The category of the visible in discourse therefore refers to what is silent, what resists understanding interpretation.

Of course, neither the instance of the "eye", nor the sphere of the visible or visuality have much in common with Lyotard's physiological qualifications. Their function is not to determine a horizon of the appearance of phenomena, but to resist the expansion of concepts that strengthen phonologocentric tendencies of the West: meaning, hearing, understanding, expressing, etc. Such understanding of visibility allows us to bring the history of linguistic representations and the history of visual representations - word and image, which have been usually separated in the Western tradition, closer together. Moreover, both discourse and image can be understood in categories other than semiological and hermeneutic: not as signs presented for reading and interpretation but as articulations of force and internal energies (there is a place here to apply psychoanalytic apparatus to the analysis of discursive and pictorial representations). Seeing should be understood, according to Lyotard, as co-determination of paths and not adopting ready meanings. Both discourse and image are like things that can be "grazed" (brouter) piece by piece, like Paul Klee's paintings were supposed to be something "torn off": "Image is not something to be read as contemporary semiologists would have it. Klee says that it is something to graze (á brouter), the thing that makes vision happen; it offers itself to the eye as an exemplary thing, as natura naturata (...) as it is makes happen the seeing of what is seeing" 18 .

Being visible and silent is both a weakness and a strength of painting. It is a field of silent reflection of vision that is pre-conceptual and puts conceptual discourse in a retreating position. The point, however, is not to highlight the limits of the possibility of philosophical reflection (condemned to the conceptual nature of its discourse) on this experience, but to follow the analysis of art of such philosophers as Merleau-Ponty, Lyotard and, with respect to literature - Barthes or Marin, to expand the very concept of reflection on art with a new understanding of the discursive.

18 Ibid., p. 14 
It allows us to connect two important aspects: it is an account of our private, pre-conceptual attitude to the world, but it also demonstrates our relationship with what is culturally and socially universal. It provides tools for recognizing the nature of the relationship between the direct, pre-linguistic, articulated in the form of emotionally charged expression, sensory-bodily layer of our experience with its layers of mediations, universalized by the system of linguistic meanings and forms of cultural communication. It is in aesthetic experience that we fulfil, with each experience anew and yet never fully, that age-old longing for the wholeness of sense and understanding. It is in the aesthetic experience that we also find what is our own, private. The sounds, shapes, colours, smells, suffering and joy of our own lives that we may find in a work of art and in the aesthetic experience of nature take on an ontological and existential grounding, leading us beyond the monadic solitude of inner experience to what is embedded in the community of existence and culturally communicable.

\section{In place of conclusion: an artist's commentary}

I have considered the tension between the existing discourses and discursiveness of art as a philosophical problem. However, it is perceived as such not only by philosophers but, above all, fuelled and articulated by artists themselves. As a conclusion to my discussion, I will give an example of a work of art created by the recently deceased, eminent Polish artist and philosopher - Grzegorz Sztabiński. It is a work that testifies to the cultural and existential significance of the theme of discursiveness of art more emphatically than any philosophical deliberation.

The work which I would like to refer to was displayed in the Marienkirche church in Frankfurt (Oder) during the Festival of New Art "Labyrinth" on 24-26 October $2014^{19}$ as part of an exhibition entitled "Nature's Scripture - Transcendence". A pile of eleven clean white sheets was placed on the bare floor of an empty interior of a closed church. On top of them, at regular intervals, in geometrical order, the artist installed bunches of dry twigs.

This installation evokes connotations on many levels. Above all, cultural and religious ones: small sacrificial pyres, primal testimonies of pagan worship; there are also connotations on the literary and philosophical level: nature in the course of its original ordering (the birth of logos - writings out of the chaos of natural randomness - as in Gombrowicz's Cosmos) enclosed in the sacred frames of an empty abandoned church, in a frame emptied of old contents,

19 Link to the festival's programme: https://ownetic.com/wydarzenia/2014/10/labirynt-festiwal-nowej-sztuki-2014-slubice/2/ 
ready to be filled with new contents, ready for a new type of sublimation. Perhaps, as the title of the exhibition would suggest, it is also about the formula of the sublime, which extends to higher levels of meaning (filling the empty space after God) - towards the natural, the cultural and human in their mutual interrelation. Above all, however, the interpretation that first comes to mind fits into the context of reflection on the discursiveness of art, which - only in the empty space left after the discourses of dead religious rituals - is capable of directing the emerging buds of meaning towards what it grows out of and what it exceeds; it is able to evoke the experience of epiphany.

Sztabiński's installation is placed in the Empty Holy Place (if you recall the term used by Żiżek / Lacana) in the most literal sense: in a German church that no longer fulfils its sacral function. Thus, it can be said that it is not in a place, but annexes it (makes the church an exhibition gallery): it incorporates the desacralisation void, incorporates it into the work of art. It is filled, permeated by the Empty Holy Place; the work of art and place lend each other rank, unlike in the case of Duchampe's ready-made objects which require "being-in" an exhibition space to be elevated to the rank of art, or Malewicz who points out that there is a formal difference between an Empty Holy Place and what is inscribed in it.

When I think about it, what irresistibly comes to mind are the words of Maurice Blanchot from The Space of Literature (p. 127): "when the gods are overthrown, the temple does not disappear with them, but, rather, it begins to appear. It reveals itself by continuing to be what it was from the first only unknowingly: the abode of the gods' absence". The Holy Empty Place - a place of lack and absence - offers an epiphanic experience of transcendence hitherto hidden under the sacred order of representation.

The sublimation proposed by Sztabiński is an account of the loss of the gap supporting the symbolic order which has been devastated by secularization processes, but at the same time leads us towards reborn symbolic order, possible only thanks to the absorption of the Void that was left after the old order. Only this act of incorporating the Void into a work of art enables transcendence towards reading the writing of nature, openness to its signs.

The fact that this interpretation of Sztabiński's work is going in the right direction is confirmed not only by the title of the series of exhibited works, but also by his own words from the catalogue description of the exhibition, which was provided to me by the Artist's daughter:

The present work is special in nature. Earlier, by repeating an arrangement of sheets of paper with fragments of twigs laid upon them, I referred to the idea, found in the Middle Ages and Romanticism, of viewing nature as a secret script that philosophers and poets were trying to decipher. 


\section{BIBLIOGRAPHY:}

R. Barthes, $S / Z$, trans. Richard Miller, Blackwell, New York, 1990.

J. F. Lyotard, Discours, figure, Klincksieck, Paris, 1985.

D. Howarth, Discourse, Open University Press, Buckingham UK, 2000.

L. Marin, De la représentaion, Gallimard, Le Seuil, Paris 1994.

M. Merleau-Ponty, The Visible and the Invisible: Followed by Working Notes. Northwestern University Press, 1968.

P. Ricoeur, Struktura a znaczenie w mowie, in: Egzystencja i hermeneutyka. Rozprawy o metodzie, trans. J. Skoczylas, Warszawa, 1985.

\section{DYSKURSYWNOŚĆ SZTUKI JAKO PROBLEM FILOZOFICZNY (streszczenie)}

Czy w sytuacji, gdy przeformułowaniu i poszerzeniu uległy zarówno pojęcia języka, jak i dyskursu oraz dyskursywności, można jeszcze rysować opozycję językowego dyskursu i sztuki, przeciwstawiać dyskursywność temu, co artystyczne? Aby odpowiedzieć na to pytanie, odróżniam pojęcia dyskursu i dyskursywności. Przenoszę to odróżnienie na poziom refleksji nad sztuką jako jedną z praktyk znaczących. Pokazuję, jak dekonstrukcja zachodnich dyskursów o sztuce towarzyszy rozpoznaniu dyskursywności sztuki przez Heideggera, Derridę, Marina; jak MerleauPonty poszukuje warunków produktywności znaczeniowej pod lub „przed” historycznie ustalonymi dyskursami i tym samym poszerza pojęcie dyskursywności sztuki w przyjętym przeze mnie rozumieniu; wiążę pojęcie wizualności u Lyotarda z proponowanym przez siebie rozumieniem dyskursywności sztuki: jako pola produktywności znaczeń, jako pierwotnego impulsu dyskursu; tego, co umożliwia mówienie i obrazowanie, bez czego nie da się mówić i obrazować.

Słowa klucze: dyskurs sztuki, dyskursywność sztuki, język, literatura, malarstwo, widzialne, niewidzialne, wizualność

Iwona Lorenc - Professor of Philosophy at the University of Warsaw, her publications include: Why Art? Introduction to the Philosophy of Art (1989), Logos and the Myth of Aestheticism (1993), Consciousness and Image. Studies on the Philosophy of Presentation (2003), French Phenomenology (coauthor, 2006), Around French Phenomenology (coauthor, 2007), Minima Aesthetica. Essays on the Aesthetics of Late Modernity (2010), The Spaces of Late Modernity (coauthor, 2011), The Aesthetic Problems of Late Modernity (2014). Author of numerous works on aesthetics and contemporary philosophy, especially French philosophy and phenomenology. 